\title{
Gender Differences in Depression across Parental Roles
}

\author{
Kevin Shafer \\ Brigham Young University - Provo, kshafer@byu.edu \\ Garrett T. Pace \\ Princeton University
}

Follow this and additional works at: https://scholarsarchive.byu.edu/facpub

Part of the Family, Life Course, and Society Commons, Gender and Sexuality Commons, Medicine and Health Commons, and the Other Sociology Commons

\section{Original Publication Citation}

Shafer, K. \& Pace, G.T.* (2015). “Gender Differences in Depression across Parental Roles.” Social Work, 60(2): 115-125.

\section{BYU ScholarsArchive Citation}

Shafer, Kevin and Pace, Garrett T., "Gender Differences in Depression across Parental Roles" (2015). Faculty Publications. 4402.

https://scholarsarchive.byu.edu/facpub/4402

This Peer-Reviewed Article is brought to you for free and open access by BYU ScholarsArchive. It has been accepted for inclusion in Faculty Publications by an authorized administrator of BYU ScholarsArchive. For more information, please contact ellen_amatangelo@byu.edu. 


\title{
Gender Differences in Depression across Parental Roles
}

\author{
Kevin Shafer and Garrett T. Pace
}

\begin{abstract}
Prior research has focused on the relationship between parenthood and psychological wellbeing, with mixed results. Some studies have also addressed potential gender differences in this relationship, again yielding varied findings. One reason may be methodological choices pursued in these studies, including the lack of focus on combined parental roles (for example, biological parent and stepparent). The authors used data from the National Longitudinal Survey of Youth, $1979(N=6,276)$ and multinomial treatment models to address how combined roles influence depressive symptoms in mothers and fathers. Further, they explored potential gender differences. Their results indicated that having multiple parental roles is negatively associated with psychological well-being for both men and women, whereas childlessness is more negative for women, and specific parental role combinations affect mothers and fathers differently. Within the context of changing family structure in the United States, these results have important implications for social workers and other mental health professionals - particularly with regard to screening for depression among parents, who are less likely to seek mental health counseling than childless adults.
\end{abstract}

KEY WORDS: children; depression; gender; multinomial treatment models; parenting

A pproximately one in six adults will experience a major depressive episode during their lifetime (Kessler et al., 2003). Because of its prevalence, depression has been termed an American "epidemic" (see, for example, Levine, 2007), affecting nearly every aspect of life: from work and income (Coryell, Endicott, \& Keller, 1990; Kessler et al., 2006) to physical health (Evans et al., 2005) and parenting behaviors (Goodman et al., 2011). Interestingly, women tend to experience, or at least report, more depressive symptoms than men. In fact, some estimates suggest that women are two to three times more likely to report depressive symptoms (Parker \& Brotchie, 2010). Yet, our understanding of what influences such differences is less well understood. One potential reason for the differences is that parenthood has unique effects on the psychological well-being of men and women.

Many parents report that having children is immensely rewarding (Nelson, Kushlev, English, Dunn, \& Lyubomirsky, 2013) but highly stressful, suggesting there may be little to no mental health benefit associated with parenthood (Evenson \& Simon, 2005). However, within the realm of parenting, some parent-child relationships appear to be more problematic than others for depressive symptomology (Pace \& Shafer, 2013). Although several studies have examined depressive symptoms of parents by gender (for example, Evenson \& Simon, 2005; Simon, 2002), most do not address the moderating effect of gender across numerous parental roles, limiting conclusions regarding psychological well-being in complex family structures. This is unfortunate, given the substantial changes in family structure (that is, divorce, cohabitation, remarriage, and so on) over recent decades that has led to greater diversification of parental roles among American adults (Cherlin, 2010; Teachman, Tedrow, \& Kim, 2013). Furthermore, understanding the risk factors for depression among parents, and if they differ by gender, is important given that parenting quality and child outcomes are related to parental depressive symptoms. Yet, screening for depression is less successful and treatment less common among mothers and fathers (National Research Council \& Institute of Medicine, 2009).

This article's goal is to specify risk factors for depressive symptoms, within the context of changing family structures in the United States, and to help improve clinical care and screening among social workers and other mental health professionals. To do so, we address how various parent-child relationships may be associated with depressive symptoms differently for men and women using data from the National Longitudinal Survey of Youth, 
1979 cohort (NLSY79), a nationally representative longitudinal study of adults who were 14 to 22 years old in 1979. Same-sex relationships and same-sex couples with children have become increasingly common in the last decade or so (Moore \& Stambolis-Ruhstorfer, 2013), insufficient data for of lesbian, gay, bisexual, and transgender (LGBT) individuals is available in NLSY79, thus limiting our analysis to only heterosexual individuals.

\section{GENDER, PARENTING, AND DEPRESSION}

Several studies report seemingly contradictory findings regarding any link between parenting and depression, let alone gender differences in this relationship. Some studies have shown a positive correlation between parenting and depression regardless of gender (Helbig, Lampert, Klose, \& Jacobi, 2006; Solmeyer \& Feinberg, 2011), whereas others show that fatherhood may lead to more adverse psychological effects than motherhood (Read \& Grundy, 2011). Still others indicate that mothers are more depressed than fathers (Carlson, 2011; Cunningham \& Knoester, 2007).

Why might the literature produce such divergent findings? Variability in how parenthood is measured may be one reason. Often, studies compare parents to nonparents, and others consider residential and nonresidential children, child age, or the child's relationship to the parent (see Evenson \& Simon, 2005, for a full discussion of these differences). Further, many studies dichotomize different parental roles (that is, has a biological child or not), without considering how these roles may combine with one another (for example, having both coresidential biological children and stepchildren). Finally, selectivity into parental roles may also matter. For example, men and women who are willing to become a stepparent may differ in substantial ways from other individuals (Amato, 2010). This means that selection effects must be taken into account when considering any link between parenting and psychological well-being.

In something of a contrast to the approach of prior studies on gender differences in the association of parenting and depression, we apply a parental roles perspective to our question (Scott \& Alwin, 1989). This framework suggests that various parent-child relationships and, more important, combinations of such relationships may be associated with depressive symptoms in parents. For instance, Pace and Shafer (2013) found that individuals with multiple parental roles (for example, biological parent and stepparent) have poorer psychological well-being than parents with a single role. Furthermore, gender and gendered parental expectations are central to understanding how parental roles are differentially associated with depressive symptoms (see, for example, Evenson \& Simon, 2005; Umberson, Pudrovska, \& Reczek, 2010). For instance, women may feel caught between their biological children and stepchildren because of traditional gender norms surrounding caregiving in families, whereas men may experience much weaker pressure from holding both roles (Stewart, 2007).

One important consideration is the number of parental roles fulfilled by an adult. Although many men and women take on one role, the number of individuals with combined roles has increased in recent decades. This is due, in part, to dramatic changes in family demography, including increased cohabitation, more nonmarital fertility, and substantial repartnering after divorce (Cherlin, 2010; Teachman et al., 2013). Numerous parental roles may be challenging because stress may ensue as individuals try to balance various roles. For example, many remarried couples care for biological children, stepchildren, and have a new biological child (Stewart, 2007). These children are often viewed as "cement children" that will bond a stepfamily together (Stewart, 2005). However, the complex family system may increase stress among adults. Other complex roles may be stressful, as well. For example, Johnson and Wu (2002) showed that having a baby can lead to psychological distress even if a couple already has a child.

\section{GENDER AND PARENTAL ROLES}

We expect gender differences in the relationship between number of parental roles and psychological well-being. In one respect, multiple parental roles may have more negative effects on men than women because the social expectations surrounding men's parental roles can vary substantially. To provide one of many possible examples, it is relatively common for a remarried man to have a nonresidential biological child from his first marriage. Ambiguity in the nonresidential parental role can manifest itself in a variety of ways - from total disengagement to a breadwinner-only attitude to high levels of involvement. Although many fathers report they want to be accessible to and involved with their children, the lack of contact between nonresidential fathers and children is high (Troilo \& 
Coleman, 2012, 2013). In contrast, men may take on a more fatherly role with their stepchildren because of their residential status (Stewart, 2007). The conflict between the desire to be a good biological father and being a good social father could be associated with increased depressive symptoms in fathers. In contrast, many women take on the primary caregiver role, even for nonbiological children (Nielsen, 1999; Shapiro \& Stewart, 2011); such similarity in expectations across women's parental roles may not increase depressive symptoms because of a lack of conflict.

However, the expectation that women take on a motherly role, even for nonbiological children, could lead to role conflict among women. One example can help illustrate how multiple roles can be problematic for the depressive symptomology of women more than men. To illustrate, stepmothers may experience elevated depressive symptoms because they are held in low regard by their stepchildren, despite their role as the primary caregiver (Fellmann, Galán, \& Lloreda, 2008; Shapiro \& Stewart, 2011). The cement child phenomenon can be particularly stressful for women. Mothers can feel caught between competing interests in the homeparticularly between biological children who feel that they will be put aside for the new child from the new relationship and the newborn and new partner (Stewart, 2007).

A third possibility is that there are no gender differences in the association between multiple parental roles and depressive symptoms. This would suggest that although the sources of stress for mothers and fathers may be different, as we have detailed earlier, the net effect of various parental roles on depressive symptoms is similar for men and women.

In this article we test for differences between men and women in the association between number of parental roles and depressive symptoms. Furthermore, as we have noted throughout the numerous examples we have discussed, there are likely to be differences by parental role combinations. To account for this we ran models to specifically focus on various sets of roles.

\section{METHOD}

\section{Data}

Our data come from NLSY79, a cohort sample of 12,686 men and women born between 1957 and 1965. Through various data restrictions we arrived at a final sample size of 6,276 . The following restrictions were imposed: (a) data collected between
1979 and 1991 were excluded because depression was first measured in 1992; (b) 1,259 respondents were lost due to data attrition between $\mathrm{T} 1$ and $\mathrm{T} 2$; and (c) 1,347 individuals refused to answer the depression questions at baseline. In some cases we were able to substitute depression score values from 1994 for depression scores in 1992. We tested for statistically significant differences between these responses but found no difference in their baseline scores or in the effect of baseline depression on T2 depression score. Full sample characteristics can be found in Table 1.

\section{Measures}

Depressive Symptoms. Our dependent measure comes from the Center for Epidemiologic Studies Depression (CES-D) seven-item scale. Although the CES-D 20-item scale is more commonly used, the CES-D 7 is also a reliable and frequently used measure of depressive symptoms (Radloff, 1977). A clinical cutoff of 16 on the 20-item scale corresponds to a cutoff of 6 on the seven-item scale. Thus, a similar percentage of individuals would be depressed on the CES-D 7 as the CES-D 20. Further, a commonly reported mean of 11 to 12 on the 20 -item scale would yield a comparable mean of 4 on the seven-item scale-which is nearly identical to the mean score reported in our sample (Comstock \& Helsing, 1976; Cseh, 2008). The seven items included in the scale assess the frequency of feeling depressed, problems eating or sleeping, difficulty focusing, and extra effort to complete normal tasks. Each individual item was assessed on a four-point Likert scale (scored 0 to 3), creating a scale ranging from 0 to 21 . Higher scores indicated the presence of more depressive symptoms. Because we were concerned with issues of selection around depression, we measured depression at baseline when respondents were between the ages of 27 and 37, and followed up with a depression measure at age 40 or 50 (T2). T2 scores were part of the NLSY health evaluation for 40and 50-year-olds. These evaluations started in 1998 when the oldest respondents turned 40. Because this would have resulted in a four- to six-year gap in evaluations, we used depression scores at age 50 whenever possible. Most T2 scores, however, were obtained in the 2000 to 2006 waves, resulting in an eight- to 12-year gap between T1 and T2 depression. Overall, Cronbach's alpha was excellent for the $\mathrm{T} 1$ and $\mathrm{T} 2$ scales, at 0.97 and 0.86 , respectively. 
Table 1: National Longitudinal Sample of Youth, 1979 Cohort, Sample Characteristics by Gender

\begin{tabular}{|c|c|c|c|c|c|c|}
\hline \multirow[b]{2}{*}{ Characteristic } & \multirow[b]{2}{*}{ Minimum } & \multirow[b]{2}{*}{ Maximum } & \multicolumn{2}{|c|}{$\begin{array}{c}\text { Women } \\
(n=3,180)\end{array}$} & \multicolumn{2}{|c|}{$\begin{array}{c}\text { Men } \\
(n=3,096)\end{array}$} \\
\hline & & & $M$ & $S D$ & $M$ & SD \\
\hline Depression score at T2 & 0 & 21 & 4.01 & 4.46 & 3.07 & 4.02 \\
\hline \multicolumn{7}{|l|}{ Number of parental roles } \\
\hline No roles & 0 & 1 & 0.27 & & 0.41 & \\
\hline 1 role & 0 & 1 & 0.39 & & 0.32 & \\
\hline 2 roles & 0 & 1 & 0.28 & & 0.22 & \\
\hline 3 roles & 0 & 1 & 0.06 & & 0.06 & \\
\hline \multicolumn{7}{|l|}{ Has biological child } \\
\hline Biological only & 0 & 1 & 0.54 & & 0.48 & \\
\hline Residential and nonresidential biological & 0 & 1 & 0.07 & & 0.03 & \\
\hline Residential biological and stepchild & 0 & 1 & 0.20 & & 0.25 & \\
\hline Nonresidential biological, stepchild, and new & 0 & 1 & 0.04 & & 0.04 & \\
\hline Residential biological and new child & 0 & 1 & 0.11 & & 0.14 & \\
\hline $\begin{array}{l}\text { Residential biological, residential stepchild, and } \\
\text { new child }\end{array}$ & 0 & 1 & 0.04 & & 0.06 & \\
\hline \multicolumn{7}{|l|}{ Has stepchild } \\
\hline Residential biological and stepchild & 0 & 1 & 0.54 & & 0.50 & \\
\hline Nonresidential biological, stepchild, and new child & 0 & 1 & 0.17 & & 0.33 & \\
\hline $\begin{array}{l}\text { Residential biological, residential stepchild, and } \\
\text { new child }\end{array}$ & 0 & 1 & 0.19 & & 0.07 & \\
\hline Stepchild only & 0 & 1 & 0.08 & & 0.07 & \\
\hline \multicolumn{7}{|l|}{ Marital status } \\
\hline Never married & 0 & 1 & 0.13 & & 0.17 & \\
\hline Previously married & 0 & 1 & 0.22 & & 0.17 & \\
\hline Cohabiting & 0 & 1 & 0.07 & & 0.09 & \\
\hline Remarried & 0 & 1 & 0.17 & & 0.15 & \\
\hline Currently in first marriage & & & 0.40 & & 0.42 & \\
\hline Depression score at $\mathrm{T} 1$ & 0 & 21 & 4.62 & 4.28 & 3.74 & 3.69 \\
\hline Full-time employment & 0 & 1 & 0.63 & & 0.67 & \\
\hline Log of income & 0 & 14 & 9.92 & 2.74 & 10.03 & 2.76 \\
\hline \multicolumn{7}{|l|}{ Educational attainment } \\
\hline Less than high school & 0 & 1 & 0.10 & & 0.13 & \\
\hline High school graduate & 0 & 1 & 0.41 & & 0.46 & \\
\hline Some college & 0 & 1 & 0.26 & & 0.20 & \\
\hline College graduate & & & 0.23 & & 0.21 & \\
\hline Southern residence & 0 & 1 & 0.41 & & 0.39 & \\
\hline Urban residence & 0 & 1 & 0.79 & & 0.79 & \\
\hline \multicolumn{7}{|l|}{ Racial/ethnic identification } \\
\hline non-Hispanic black & 0 & 1 & 0.30 & & 0.31 & \\
\hline Hispanic & 0 & 1 & 0.20 & & 0.20 & \\
\hline non-Hispanic white & & & 0.50 & & 0.49 & \\
\hline \multicolumn{7}{|l|}{ Religious affiliation } \\
\hline Catholic & 0 & 1 & 0.36 & & 0.34 & \\
\hline Conservative Protestant & 0 & 1 & 0.30 & & 0.30 & \\
\hline Other religious affiliation & 0 & 1 & 0.11 & & 0.11 & \\
\hline No religious affiliation & 0 & 1 & 0.03 & & 0.05 & \\
\hline Mainline Protestant & & & 0.20 & & 0.21 & \\
\hline Attends church frequently & 0 & 1 & 0.20 & & 0.16 & \\
\hline Age 50 at $\mathrm{T} 2$ & 0 & 1 & 0.26 & & 0.24 & 2.61 \\
\hline
\end{tabular}


Parental Roles. Our measures of parental roles are derived from the NLSY79 household roster, which includes information on each individual's relationship to the respondent and specific questions on children and their residential status. In our first set of models we consider number of parental roles, including a set of measures addressing the number of unique parental roles held by a respondent. These parental roles can include being a parent of a residential biological child, a nonresidential biological child, a new biological child between $\mathrm{T} 1$ and T2, a residential stepchild, or a nonresidential stepchild, and not being a parent. We included dichotomous variables for $0,1,2$, or 3 parental roles. In additional models we included variables for different combinations of parental roles from the same list.

Gender. We included a dichotomous variable for whether the respondent identified as a woman or man.

Control Variables. We included controls for depression score at T1, marital status, full-time employment, family income (logged), educational attainment, urban residence, southern residence, racial or ethnic identification, religious identification and attendance, and age at which T2 depression was measured.

\section{Analytic Strategy}

One methodological concern was that individuals enter parental roles selectively. For example, individuals who willingly form stepfamilies or choose to have a new child may be qualitatively different from those who do not (for example, Shafer \& James, 2013). Because of this concern, we used multinomial treatment models (MTMs) (Deb \& Trivedi, 2006), which account for selection into different parental roles. MTMs are done in two stages. In the first stage, selection is modeled via a set of variables that may be associated with entry into various parental roles, including sociodemographic factors, psychological well-being, and other characteristics (these variables are listed in Table 1, excluding depression score at $\mathrm{T} 2$ and parental roles variables). In the second stage, we modeled the CES-D depression score onto the independent and control variables. Because the second stage includes corrections for selection (as noted by $\Lambda$ variables), the model allows us to better isolate any association between parental roles and psychological wellbeing with diminished or eliminated selection issues. Finally, to account for the potential of multiple comparison bias in our large sample, we adjusted the significance tests using the qqvalue package in Stata 13.0. For each of our reported models the results were substantively unchanged from uncorrected $t$ tests using both a Šidák correction and the more conservative Bonferroni correction, suggesting that multiple comparisons were not an issue in our data. In addition, the multinomial selection

\begin{tabular}{|c|c|c|c|c|c|c|}
\hline \multirow[b]{2}{*}{ Characteristic } & \multicolumn{2}{|c|}{$\begin{array}{c}\text { Full Sample } \\
(N=6,276)\end{array}$} & \multicolumn{2}{|c|}{$\begin{array}{c}\text { Women } \\
(n=3,180)\end{array}$} & \multicolumn{2}{|c|}{$\begin{array}{c}\text { Men } \\
(n=3,096)\end{array}$} \\
\hline & $M$ & SD & M & SD & $M$ & SD \\
\hline \multicolumn{7}{|l|}{ Number of parental roles $(n=6,276)$} \\
\hline No roles & 4.04 & 4.63 & 4.75 & 4.94 & 3.56 & 4.34 \\
\hline 1 role & 3.03 & 3.89 & 3.42 & 4.07 & 2.54 & 3.59 \\
\hline 2 roles & 3.50 & 4.15 & 4.05 & 4.40 & 2.78 & 3.69 \\
\hline 3 roles & 4.05 & 4.57 & 4.46 & 4.40 & 3.59 & 4.71 \\
\hline \multicolumn{7}{|l|}{ Has biological child $(n=3,534)$} \\
\hline Biological only & 2.89 & 3.72 & 3.32 & 3.95 & 2.21 & 3.21 \\
\hline Residential and nonresidential biological child & 4.27 & 4.60 & 4.49 & 4.77 & 3.43 & 3.87 \\
\hline Residential biological and stepchild & 3.52 & 4.05 & 4.04 & 4.19 & 2.92 & 3.79 \\
\hline Nonresidential biological child, stepchild, and new child & 3.89 & 4.54 & 4.25 & 4.89 & 4.05 & 5.06 \\
\hline Residential biological and new child & 2.98 & 3.97 & 3.86 & 4.69 & 2.02 & 2.69 \\
\hline Residential biological, residential stepchild, and new child & 4.05 & 4.39 & 4.86 & 4.18 & 3.73 & 4.83 \\
\hline \multicolumn{7}{|l|}{ Has stepchild $(n=1,626)$} \\
\hline Residential biological child and stepchild & 3.51 & 4.05 & 4.04 & 4.19 & 2.92 & 3.79 \\
\hline Nonresidential biological, stepchild, and new child & 4.13 & 4.52 & 4.25 & 4.89 & 4.05 & 5.06 \\
\hline Residential biological, residential stepchild, and new child & 3.89 & 4.54 & 4.86 & 4.18 & 3.73 & 4.83 \\
\hline Stepchild only & 4.05 & 4.39 & 4.01 & 4.35 & 3.31 & 4.46 \\
\hline
\end{tabular}


term adjusts the standard errors of the slopes, which helps account for potential alpha comparison issues.

\section{RESULTS}

\section{Descriptive Results}

The means and standard deviations for T2 depression score are reported in Table 2. Three separate mean scores, for the full sample and by gender, are provided. With regard to number of roles, we find that, overall, individuals with no child or three parental roles report the highest depression scores, which is present regardless of gender-although women report more depressive symptoms if they have no children than three parental roles. Women, as compared with men, consistently report higher levels of depressive symptoms, regardless of the number of parental roles, as detailed in Table 2.

\section{Main Effects Models}

The results of our main effects regressions are reported in Table 3. In the first regression we focused on the number of parental roles held by the respondent. Overall, we found that compared with having one parental role (that is, biological parent only or stepparent only), having three parental roles was significantly associated with poorer psychological well-being $(b=0.764, p<.05)$. We also noted that women had higher depression scores than men $(b=$ $0.763, p<.001)$. The variables entered into the regression to account for self-selection are not significant, except in the case of $\Lambda_{\text {(two roles) }}$, which is significant and positive, suggesting that the unobserved characteristics associated with selection into two parental roles are positively associated with higher depression scores.

In the next model we limited our subsample to only those respondents who reported having a biological child. Here, we saw some differences based on parental roles. Compared with those who had only biological children at home, individuals with both residential and nonresidential biological children $(b=1.436, p<.001)$, a residential biological child and stepchild $(b=1.422, p<.001)$, and a biological child, stepchild, and new child in the home $(b=$ 1.236, $p<.01)$ had higher depression scores. Again, we found a significant difference in the depression scores of men and women $(b=0.500, p<.001)$. $\Lambda_{\text {(RB-NRB) }}$ and $\Lambda_{\text {(RB-S) }}$ are significant and negative, suggesting that the selective factors associated with entry into these parental roles are negatively associated with depressive symptoms. In model 3 we compared three parental role types or combinations with individuals who had a biological child and a stepchild. Our results showed that, compared with this group, only respondents with a nonresidential biological child, stepchild, and new child experienced significantly higher levels of psychological distress than the reference group $(b=1.490$, $p<.01)$. Again, we found a significant gender difference in psychological well-being, and many of the significant control variables in models 1 and 2 were also significant in model 3 . Only $\Lambda_{\text {(NRB-S-NEW) }}$ was significantly and negatively associated with depression score.

\section{Interaction Models}

Table 4 reports the main and interaction effects between gender (female) and parental roles. Note that we include all of the controls reported in Table 3, but do not report them here because of substantial similarities in coefficient size and statistical significance in the main effects and interactive models. In model 1, which addresses number of parental roles, the main effects show that both men and women experience an increase in depressive symptoms when they have three parental roles-no gender difference was found. A significant gender difference was found between men and women without children, with women having depression scores 0.631 points higher than childless men. Similarly, women with one parental role also reported more depressive symptoms than men-as noted by the significant main effect $(b=0.441, p<.01)$.

In Model 2, where we limited the subsample to only individuals with a biological child, we found differences between men and women with only biological children and those with residential biological and new children. For individuals with only a biological child, women had depression scores that were, on average, 0.406 points higher than those for men $(p<.05)$. Meanwhile, although having a residential biological child and a new child decreased depressive symptoms in men $(b=-0.686$, $p<.05)$, the same pairing actually increased the number of depressive symptoms in women $(b=$ $0.747, p<.01)$. In model 3 , which includes only respondents with a stepchild, we found that compared with men with a residential biological child and stepchild, men with a nonresidential biological child, stepchild, and new child had depression scores that were, on average, almost 2.2 points higher $(p<.01)$. In contrast, women with the same set 

Table 3: Main Effects Multinomial Treatment Models of Center for Epidemiologic Studies
Depression Score on Parental Roles, Gender, and Control Variables

\begin{tabular}{|c|c|c|c|c|c|c|}
\hline \multirow[b]{2}{*}{ Characteristic } & \multicolumn{2}{|c|}{$\begin{array}{l}\text { Model 1: Number } \\
\text { of Parental Roles }\end{array}$} & \multicolumn{2}{|c|}{$\begin{array}{l}\text { Model 2: Has } \\
\text { Biological Child }\end{array}$} & \multicolumn{2}{|c|}{$\begin{array}{l}\text { Model 3: Has } \\
\text { Stepchild }\end{array}$} \\
\hline & $\boldsymbol{b}$ & SE & $\boldsymbol{b}$ & SE & $\boldsymbol{b}$ & SE \\
\hline \multicolumn{7}{|l|}{ Parental roles } \\
\hline No parental role & -0.223 & 0.294 & & & & \\
\hline 1 parental role & $R E F$ & & & & & \\
\hline 2 parental roles & -0.281 & 0.286 & & & & \\
\hline 3 parental roles & 0.764 & $0.368^{*}$ & & & & \\
\hline Biological child only & & & $R E F$ & & & \\
\hline Residential and nonresidential biological child & & & 1.436 & $0.391^{* * *}$ & & \\
\hline Residential biological child and stepchild & & & 1.422 & $0.278^{* * *}$ & & \\
\hline $\begin{array}{l}\text { Nonresidential biological child, stepchild, and } \\
\text { new child }\end{array}$ & & & 0.423 & 0.402 & 1.490 & $0.513^{* *}$ \\
\hline Residential biological child and new child & & & -0.288 & 0.319 & & \\
\hline $\begin{array}{l}\text { Residential biological child, residential } \\
\text { stepchild, and new child }\end{array}$ & & & 1.236 & $0.395^{* *}$ & 0.801 & 0.503 \\
\hline Stepchild only & & & & & -0.466 & 0.400 \\
\hline Women & 0.673 & $0.107^{* * *}$ & 0.500 & $0.137^{* * *}$ & 0.495 & $0.213^{*}$ \\
\hline \multicolumn{7}{|l|}{ Marital status } \\
\hline First married & $R E F$ & & $R E F$ & & & \\
\hline Never married & 0.799 & $0.223^{* * *}$ & 0.993 & $0.287^{* *}$ & 0.828 & 0.531 \\
\hline Previously married & 0.819 & $0.161^{* * *}$ & 0.732 & $0.193^{* * *}$ & 0.785 & $0.291^{* *}$ \\
\hline Cohabiting & 0.196 & 0.211 & 0.247 & 0.278 & 0.460 & 0.437 \\
\hline Remarried & 0.337 & $0.148^{*}$ & -0.053 & 0.180 & 0.546 & $0.263^{*}$ \\
\hline Depression at $\mathrm{T} 1$ & 0.283 & $0.013^{* * *}$ & 0.283 & $0.017^{* * *}$ & 0.310 & $0.025^{* * *}$ \\
\hline Full-time employment & -0.910 & $0.124^{* * *}$ & -0.801 & $0.154^{* * *}$ & -1.039 & $0.232^{* * *}$ \\
\hline Log of income & -0.128 & $0.021^{* * *}$ & -0.079 & $0.030^{* *}$ & -0.083 & 0.045 \\
\hline \multicolumn{7}{|l|}{ Educational attainment } \\
\hline Less than high school & 1.134 & $0.198^{* * *}$ & 0.843 & $0.267^{* *}$ & 1.853 & $0.397^{* * *}$ \\
\hline High school graduate & 0.451 & $0.138^{* *}$ & 0.459 & $0.166^{* *}$ & 0.367 & 0.274 \\
\hline Some college & 0.261 & 0.151 & 0.263 & 0.182 & 0.211 & 0.301 \\
\hline College graduate & $R E F$ & & $R E F$ & & & \\
\hline Southern residence & 0.117 & 0.110 & 0.087 & 0.139 & -0.168 & 0.222 \\
\hline Urban residence & -0.071 & 0.124 & 0.058 & 0.154 & 0.035 & 0.244 \\
\hline \multicolumn{7}{|l|}{ Racial/ethnic identification } \\
\hline non-Hispanic white & $R E F$ & & $R E F$ & & & \\
\hline non-Hispanic black & -0.339 & $0.140^{*}$ & -0.484 & $0.181^{* *}$ & -0.599 & $0.266^{*}$ \\
\hline Hispanic & -0.268 & 0.154 & -0.368 & $0.186^{*}$ & -0.508 & 0.293 \\
\hline \multicolumn{7}{|l|}{ Religious affiliation } \\
\hline Mainline Protestant & $R E F$ & & $R E F$ & & & \\
\hline Catholic & -0.221 & 0.155 & -0.352 & 0.189 & -0.375 & 0.304 \\
\hline Conservative Protestant & 0.209 & 0.158 & 0.250 & 0.202 & 0.178 & 0.313 \\
\hline Other religious affiliation & 0.152 & 0.189 & 0.085 & 0.237 & 0.305 & 0.363 \\
\hline No religious affiliation & 0.138 & 0.276 & 0.465 & 0.358 & 1.421 & $0.564^{*}$ \\
\hline Frequently attends church & -0.050 & 0.031 & 0.011 & 0.039 & -0.078 & 0.061 \\
\hline Age 50 at $\mathrm{T} 2$ & 0.100 & $0.025^{* * *}$ & -0.042 & 0.038 & 0.098 & $0.020^{* * *}$ \\
\hline Constant & -196.505 & & 87.568 & & 3.466 & \\
\hline$N$ & 6276 & & 3534 & & 1626 & \\
\hline$X^{2}$ & $3307.29^{* * *}$ & & 2057.99 & & $672.24^{* * *}$ & \\
\hline Log pseudo-likelihood & -23885.63 & & -13171.60 & & -6502.19 & \\
\hline $\ln (\sigma)$ & 1.347 & $0.018^{* * *}$ & 1.186 & $0.033^{* * *}$ & 1.293 & $0.042^{* * *}$ \\
\hline$\Lambda$ (no roles) & 0.474 & 0.299 & & & & \\
\hline
\end{tabular}




\begin{tabular}{|c|c|c|c|c|c|c|}
\hline \multirow[b]{2}{*}{ Characteristic } & \multicolumn{2}{|c|}{$\begin{array}{l}\text { Model 1: Number } \\
\text { of Parental Roles }\end{array}$} & \multicolumn{2}{|c|}{$\begin{array}{l}\text { Model 2: Has } \\
\text { Biological Child }\end{array}$} & \multicolumn{2}{|c|}{$\begin{array}{l}\text { Model 3: Has } \\
\text { Stepchild }\end{array}$} \\
\hline & b & SE & b & SE & b & SE \\
\hline$\Lambda$ (two roles) & 0.574 & $0.291^{*}$ & & & & \\
\hline$\Lambda$ (three roles) & -0.105 & 0.347 & & & & \\
\hline$\Lambda$ (residential and nonresidential biological child) & & & -0.936 & $0.309^{* *}$ & & \\
\hline$\Lambda$ (residential biological child and stepchild) & & & -1.214 & $0.248^{* * *}$ & & \\
\hline $\begin{array}{l}\Lambda \text { (nonresidential biological child, stepchild, and } \\
\text { new child) }\end{array}$ & & & 0.347 & 0.265 & -1.254 & $0.421^{* *}$ \\
\hline$\Lambda$ (residential biological and new child) & & & 0.439 & 0.284 & & \\
\hline$\Lambda$ (residential biological child, stepchild, and new child) & & & -0.177 & 0.258 & -0.330 & 0.419 \\
\hline$\Lambda$ (stepchild only) & & & & & 0.203 & 0.357 \\
\hline
\end{tabular}

of roles had depression scores lower than men $(b=$ $-1.179, p<.05)$.

\section{DISCUSSION}

Overall, our results suggest that having a high number of parental roles is problematic for both men and women. For men this may result from the different expectations placed on fathers, depending on their relationship with their children. For example, our models showed that having "cement children" where biological, step, and new children coexist can increase depressive symptoms compared with individuals with one parental role. Cement children can be particularly problematic for men if their biological child does not regularly reside with them. In such a scenario these roles can conflict; does the father owe more time and fathering to his biological child, in spite of the fact that they do not co-reside? Or, does attention fall to the stepchild? And, does the presence of a new child make both the biological and stepchild feel pushed aside for the new child from the new relationship? These are questions not easily answered, yet they are frequently confronted by both mothers and fathers. Furthermore, these issues are becoming more common as families in the United States become increasingly diverse (Sweeney, 2010).

We found other gender differences in the relationship between parental roles and depression, as well. Women without children experienced more depressive symptoms, on average, than men. To some extent, this seems to be in contrast to the notion that nonparents tend to have better mental health than any type of parent (Evenson \& Simon, 2005). However, some of this may have to do with the pressure many women, particularly in this age group, face to become mothers; or, the realization that they may never become a (biological) mother, given that the women at T2 are either 40 or 50 years old. Men, on the other hand, appear to feel no ill effects of childlessness. When focusing on parental roles and combinations we found that women with a biological child and a new child exhibit more depressive symptoms than men with the same roles. This may be due to the higher demands placed on women with new children, such as feeding and sleeplessness (Hunter, Rychnovsky, \& Yount, 2009). As previously mentioned, the only combination of roles in which men experienced more depressive symptoms than women was when they had a nonresidential biological child, stepchild, and new child.

It is important to recognize that, more often than not, different parental roles have a similar influence on the depressive symptoms of mothers and fathers. One potential explanation comes from recent changes in social definitions and expectations of mothering and fathering. Today, the division of child care and household responsibilities are somewhat more equally distributed between parents than in the past (Bianchi, Milkie, Sayer, \& Robinson, 2000; Lee, Schneider, \& Waite, 2003). Arguably, parental roles are becoming less traditional, and that might explain the overall similarities across gender.

\section{Limitations}

Of course, there are limitations to our study. Depression was only measured at two time pointsage 27 to 37 and age 40 or 50 . It would have been beneficial to measure symptoms more frequently. Other child characteristics beyond the nature of the parent-child relationship, such as child's gender, were not included in our models-mostly due to the lack of sufficient data on nonbiological children and the 
Table 4: Multinomial Treatment Models of Center for Epidemiologic Studies Depression Score with Interactions between Gender and Parental Roles

\begin{tabular}{|c|c|c|c|c|c|c|}
\hline \multirow[b]{2}{*}{ Characteristic } & \multicolumn{2}{|c|}{$\begin{array}{l}\text { Model } 1 \text { Number of } \\
\text { Parental Roles }\end{array}$} & \multicolumn{2}{|c|}{$\begin{array}{l}\text { Model } 2 \text { Has } \\
\text { Biological Child }\end{array}$} & \multicolumn{2}{|c|}{$\begin{array}{l}\text { Model } 3 \text { Has } \\
\text { Step Child }\end{array}$} \\
\hline & $\boldsymbol{b}$ & SE & b & SE & b & SE \\
\hline \multicolumn{7}{|l|}{ Parental roles } \\
\hline No parental role & -0.519 & 0.319 & & & & \\
\hline 1 parental role & $R E F$ & & & & & \\
\hline 2 parental roles & -0.354 & 0.321 & & & & \\
\hline 3 parental roles & 0.875 & $0.221^{*}$ & & & & \\
\hline Biological child only & & & $R E F$ & & & \\
\hline Residential and nonresidential biological child & & & 1.742 & $0.654^{* *}$ & & \\
\hline Residential biological child and stepchild & & & 1.366 & $0.331^{* * *}$ & $R E F$ & \\
\hline Nonresidential biological child, stepchild, and new child & & & 0.886 & 0.553 & 2.194 & $0.669^{* *}$ \\
\hline Residential biological child and new child & & & -0.686 & $0.197^{*}$ & & \\
\hline $\begin{array}{l}\text { Residential biological child, residential stepchild, and } \\
\text { new child }\end{array}$ & & & 0.988 & $0.291^{*}$ & 0.557 & 0.610 \\
\hline Stepchild only & & & & & -0.402 & 0.667 \\
\hline Female & 0.441 & $0.171^{* *}$ & 0.406 & $0.184^{*}$ & 0.434 & 0.295 \\
\hline \multicolumn{7}{|l|}{ Interactions } \\
\hline Female $\times$ no role & 0.631 & $0.122^{* *}$ & & & & \\
\hline Female $\times 2$ roles & 0.137 & 0.260 & & & & \\
\hline Female $\times 3$ roles & -0.224 & 0.443 & & & & \\
\hline Female $\times$ residential and nonresidential biological child & & & -0.394 & 0.658 & & \\
\hline Female $\times$ residential biological child and stepchild & & & 0.094 & 0.316 & & \\
\hline $\begin{array}{l}\text { Female } \times \text { nonresidential biological child, stepchild, and } \\
\text { new child }\end{array}$ & & & -0.777 & 0.636 & -1.179 & $0.351^{*}$ \\
\hline Female $\times$ residential biological child and new child & & & 0.747 & $0.221^{* *}$ & & \\
\hline $\begin{array}{l}\text { Female } \times \text { residential biological child, stepchild, and } \\
\text { new child }\end{array}$ & & & 0.504 & 0.606 & 0.470 & 0.677 \\
\hline Female $\times$ stepchild only & & & & & 0.465 & 0.498 \\
\hline Constant & -19.926 & & 8.823 & & 3.445 & \\
\hline$N$ & 6276 & & 3534 & & 1626 & \\
\hline$X^{2}$ & $3318.50^{* * *}$ & & $2066.01^{* * *}$ & & $678.58^{* * *}$ & \\
\hline Log pseudo-likelihood & -23881.44 & & -13168.20 & & -6499.75 & \\
\hline $\ln (\sigma)$ & 1.347 & $0.018^{* * *}$ & 1.186 & $0.034^{* * *}$ & 1.292 & $0.042^{* * *}$ \\
\hline$\Lambda$ (no roles) & 0.456 & 0.304 & & & & \\
\hline$\Lambda$ (two roles) & 0.576 & $0.147^{*}$ & & & & \\
\hline$\Lambda$ (three roles) & -0.096 & 0.351 & & & & \\
\hline$\Lambda$ (residential and nonresidential biological child) & & & -0.918 & $0.322^{* *}$ & & \\
\hline$\Lambda$ (residential biological child and stepchild) & & & -1.215 & $0.252^{* * *}$ & & \\
\hline$\Lambda$ (nonresidential biological child, stepchild, and new child) & & & 0.345 & 0.269 & 0.174 & 0.363 \\
\hline$\Lambda$ (residential biological and new child $)$ & & & 0.437 & 0.289 & & \\
\hline$\Lambda$ (residential biological child, stepchild, and new child) & & & -0.189 & 0.264 & 0.628 & 0.424 \\
\hline$\Lambda$ (stepchild only) & & & & & -0.334 & 0.421 \\
\hline
\end{tabular}

substantial complexity of some households in the NLSY sample. Furthermore, the data lacked a sufficient number of individuals in same-sex relationships to understand whether the dynamics of parenting and depression differ from the heteronormative relationships we addressed here. Despite these limitations, our study possesses strengths. We used nationally representative longitudinal data with considerably detailed family demographics, while accounting for issues of selectivity. We included men and women in our sample, and tested a considerable number of potential gender differences across numerous parental roles. In contrast, the majority of studies on parenting only include women in their respective samples and usually lack detail in the modeling of parental roles. 


\section{Implications}

Our findings have implications for social workers and other mental health professionals. Unfortunately, most screening programs for depression do not assess whether the adult is a parent (National Research Council \& Institute of Medicine, 2009, p. 5). We recommend modifying screening, when possible, to consider whether the person is a parent and their specific parental roles, which may increase depressive symptoms. Whereas any parental role might be problematic for mental health on the individual level, our findings provide empirical evidence for certain inquiries. For men, among the most problematic parental roles are having a nonresidential biological child, stepchild, and a new child; or having a residential biological and a nonresidential child. For women, childlessness might be a risk factor; and having a residential biological and new child might also be problematic. Both genders appear to be at greater risk when they experience three parental roles. If any of these risk factors are identified during the administration of a screening tool, or during an interview or therapeutic session, we recommend that professionals inquire further to determine any influence these roles might have on the consumer's mental health and perhaps their parenting practices (Goodman et al., 2011).

\section{CONCLUSION}

Depression is a prevalent mental health condition in society. Parenthood is one of the risk factors for increased depressive symptoms, and certain parental roles are clearly more problematic than others. We found that across numerous roles, men and women seem to experience similar risk for higher depressive symptoms, yet there were also important differences across genders. Indeed, our research has demonstrated the utility of detailed family demographics and addressing some of the complexities of postmodern parenthood in explaining parental mental health. SW

\section{REFERENCES}

Amato, P. (2010). Research on divorce: Continuing trends and new developments. Journal of Marriage and Family, 72, 650-666.

Bianchi, S. M., Milkie, M. A., Sayer, L. C., \& Robinson, J. P. (2000). Is anyone doing the housework? Trends in the gender division of household labor. Social Forces, 79(1), 191-228.

Carlson, D. L. (2011). Explaining the curvilinear relationship between age at first birth and depression among women. Social Science \& Medicine, 72, 494-503.

Cherlin, A. J. (2010). Demographic trends in the United States: A review of research in the 2000s. Journal of Marriage and Family, 72, 403-419.
Comstock, G. W., \& Helsing, K. J. (1976). Symptoms of depression in two communities. Psychological Medicine, 6, 551-563.

Coryell, W., Endicott, J., \& Keller, M. (1990). Outcome of patients with chronic affective disorder: A five-year follow-up. American Journal of Psychiatry, 147, 1627-1633.

Cseh, A. (2008). The effects of depressive symptoms on earnings. Southern Economic Journal, 75, 383-409.

Cunningham, A. M., \& Knoester, C. (2007). Marital status, gender, and parents' psychological well-being. Sociological Inquiry, 77(2), 264-287.

Deb, P., \& Trivedi, P. K. (2006). Specification and simulated likelihood estimation of a non-normal treatment-outcome model with selection: Application to health care utilization. Econometrics Journal, 9(2), 307-331.

Evans, D. L., Charney, D. S., Lewis, L., Golden, R. N., Gorman, J. M., Krishnan, K.R.R., et al. (2005). Mood disorders in the medically ill: Scientific review and recommendations. Biological Psychiatry, 58, 175-189.

Evenson, R. J., \& Simon, R. W. (2005). Clarifying the relationship between parenthood and depression. Journal of Health and Social Behavior, 46, 341-358.

Fellmann, I. E., Galán, M.J.C., \& Lloreda, M.J.H. (2008). Stepparent role strain and psychological distress. Psicothema, 20, 732-738.

Goodman, S. H., Rouse, M. H., Connell, A. M., Broth, M. R., Hall, C. M., \& Heyward, D. (2011). Maternal depression and child psychopathology: A meta-analytic review. Clinical Child and Family Psychology Review, 14(1), 1-27.

Helbig, S., Lampert, T., Klose, M., \& Jacobi, F. (2006). Is parenthood associated with mental health? Social Psychiatry and Psychiatric Epidemiology, 41, 889-896.

Hunter, L. P., Rychnovsky, J. D., \& Yount, S. M. (2009). A selective review of maternal sleep characteristics in the postpartum period. Journal of Obstetric, Gynecologic, \& Neonatal Nursing, 38(1), 60-68.

Johnson, D. R., \& Wu, J. (2002). An empirical test of crisis, social selection, and role explanations of the relationship between marital disruption and psychological distress: A pooled time-series analysis of four-wave panel data. Journal of Marriage and Family, 64, 211-224.

Kessler, R. C., Akiskal, H. S., Ames, M., Birnbaum, H., Greenberg, P., Hirschfeld, R. M., et al. (2006). The prevalence and effects of mood disorders on work performance in a nationally representative sample of US workers. American Journal of Psychiatry, 163, 1561-1568.

Kessler, R. C., Berglund, P., Demler, O., Jin, R., Koretz, D., Merikangas, K. R., et al. (2003). The epidemiology of major depressive disorder. JAMA, 289, 3095-3105.

Lee, Y. S., Schneider, B., \& Waite, L. J. (2003). Children and housework: Some unanswered questions. Sociological Studies of Children and Youth, 9, 105-125.

Levine, B. (2007). Surviving America's depression epidemic: How to find morale, energy, and community in a world gone crazy. White River Junction, VT: Chelsea Green Publishing.

Moore, M. R., \& Stambolis-Ruhstorfer, M. (2013). LGBT sexuality and families at the start of the twenty-first century. Annual Review of Sociology, 39, 491-507.

National Research Council \& Institute of Medicine. (2009). Depression in parents, parenting, and children: Opportunities to improve identification, treatment, and prevention. Board on Children, Youth, and Families, Division of Behavioral and Social Sciences and Education. Washington, DC: National Academies Press.

Nelson, S. K., Kushlev, K., English, T., Dunn, E. W., \& Lyubomirsky, S. (2013). In defense of parenthood: Children are associated with more joy than misery. Psychological Science, 24(1), 3-10. 
Nielsen, L. (1999). Stepmothers: Why so much stress? A review of the research. Journal of Divorce \& Remarriage, 30(1-2), 115-148.

Pace, G. T., \& Shafer, K. (2013). Parenting and depression: Differences across parental roles. Journal of Family Issues. Advance online publication. doi:10.1177/ 0192513X13506705

Parker, G., \& Brotchie, H. (2010). Gender differences in depression. International Review of Psychiatry, 22, 429-436.

Radloff, L. S. (1977). The CES-D scale: A self-report depression scale for research in the general population. Applied Psychological Measurement, 1, 385-401.

Read, S., \& Grundy, E. (2011). Mental health among older married couples: The role of gender and family life. Social Psychiatry and Psychiatric Epidemiology, 46, 331-341.

Scott, J., \& Alwin, D. F. (1989). Gender differences in parental strain: Parental role or gender role? Journal of Family Issues, 10, 482-503.

Shafer, K., \& James, S. L. (2013). Gender and socioeconomic status differences in first and second marriage formation. Journal of Marriage and Family, 75, 544-564.

Shapiro, D. N., \& Stewart, A. J. (2011). Parenting stress, perceived child regard, and depressive symptoms among stepmothers and biological mothers. Family Relations, 60, 533-544.

Simon, R. W. (2002). Revisiting the relationships among gender, marital status, and mental health. American Journal of Sociology, 107, 1065-1096.

Solmeyer, A. R., \& Feinberg, M. E. (2011). Mother and father adjustment during early parenthood: The roles of infant temperament and coparenting relationship quality. Infant Behavior and Development, 34, 504-514.

Stewart, S. D. (2005). How the birth of a child affects involvement with stepchildren. Journal of Marriage and Family, 67, 461-473.

Stewart, S. D. (2007). Brave new stepfamilies: Diverse paths toward stepfamily living. Thousand Oaks, CA: Sage Publications.

Sweeney, M. M. (2010). Remarriage and stepfamilies: Strategic sites for family scholarship in the 21 st century. Journal of Marriage and Family, 72, 667-684.

Teachman, J., Tedrow, L., \& Kim, G. (2013). The demography of families. In G. W. Peterson \& K. R. Bush (Eds.), Handbook of marriage and family (pp. 39-63). New York: Springer.

Troilo, J., \& Coleman, M. (2012). Nonresidential fathers' identities after divorce. Family Relations, 61, 601-614.

Troilo, J., \& Coleman, M. (2013). "I don't know how much more I can take": How divorced nonresidential fathers manage barriers to involvement? Fathering: A Journal of Theory, Research, and Practice about Men as Fathers, 11(2), 159-178.

Umberson, D., Pudrovska, T., \& Reczek, C. (2010). Parenthood, childlessness, and well-being: A life course perspective. Journal of Marriage and Family, 72, 612-629.

Kevin Shafer, PhD, is assistant professor, School of Social Work, Brigham Young University, Provo, UT 84663; e-mail: kevinshafer@byu.edu. Garrett T. Pace, MSW, is a research specialist, population research, Princeton University, Princeton, NJ.

Original manuscript received October 29, 2013 Accepted November 18, 2013

Advance Access Publication February 5, 2015

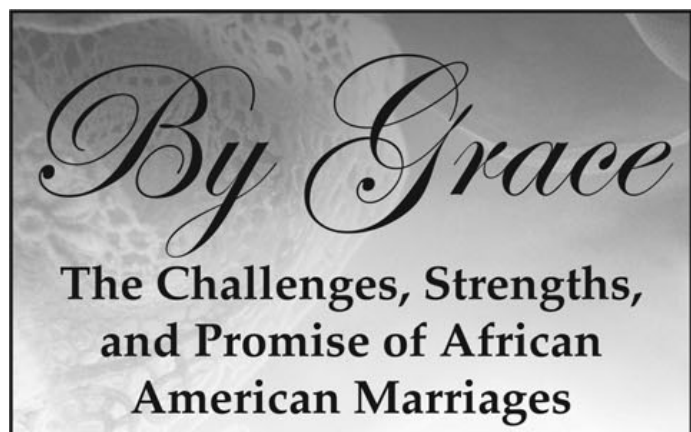

Tricia B. Bent-Goodley, Editor

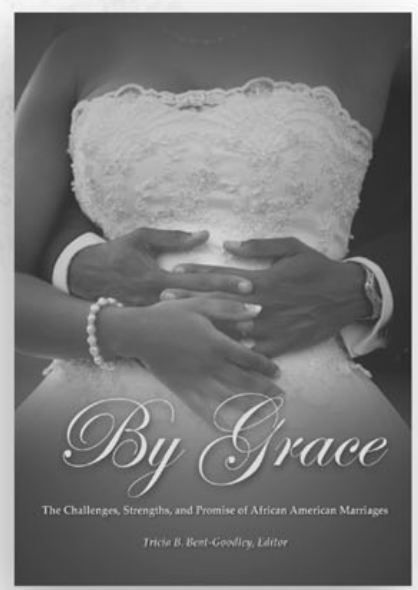

By Grace: The Challenges, Strengths, and Promise of African American Marriages examines contemporary and historical issues that have affected black marriages, relationships, and families. The chapters explore major topics as they relate to African American marriages, including economics, caregiving across the life span, mental illness, health, gender roles and relationships, and social policy. By Grace highlights the strengths and resilience of African American relationships. The book is written for diverse professional and community audiences. It can be used by couples to explore some of the challenges they experience in their marriages to support healthy relationship building. The book also serves as a resource and provides practical approaches for practitioners.

ISBN: 978-0-87101-451-1. 2014. Item \#4511. 184 pages. \$34.99

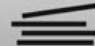

1-800-227-3590 www.naswpress.org
NASW CODE:APBG14 